\title{
Altered connective tissue in children with congenital dislocation of the hip
}

\author{
NIS FREDENSBORG and ALF UDÉN \\ From the Department of Orthopaedic Surgery, Malmö General Hospital, University of Lund, Sweden
}

\begin{abstract}
Fredensborg, N., and Udén, A. (1976). Archives of Disease in Childhood, 51, 887. Altered connective tissue in children with congenital dislocation of the hip. The umbilical cord was employed as a source of collagen in 10 children with congenital dislocation of hip. The amount of collagen and its solubility were measured in slices of the cords and in the umbilical veins and compared with the values in normal subjects. Both the amount of collagen and its solubility were decreased in children with congenital dislocation of the hip.
\end{abstract}

The laxity of connective tissue structures in children with congenital dislocation of the hip $(\mathrm{CDH})$ is well known. Andrén (1960) showed pelvic instability and several investigators (Carter and Wilkinson, 1964; Wynne-Davies, 1970) have described general joint laxity in these children.

Hormonal influence of oestrogens as a factor in the aetiology of $\mathrm{CDH}$ was proposed by Andrén (1960) and Andrén and Borglin (1960, 1961a, b). Oestrogen-induced changes in the connective tissue of joint capsule and ligaments might be responsible for the increased laxity. Collagen is the major constituent of connective tissue and is responsible for the tensile strength of ligaments and joint capsule (Grant and Prockop, 1972). We have investigated the amount of collagen and the solubility of collagen in weak organic acid in order to assess the degree of cross-linking (Jackson and Bentley, 1960), since cross-linking is related to the physical properties of the connective tissue in structures such as joint ligaments. As biopsy material from ligament and joint capsule was unavailable the umbilical cord was used.

\section{Material and methods}

Umbilical cords were collected from about 5000 consecutive newborns, and stored at $-30^{\circ} \mathrm{C}$ until examined. Within 24 hours after delivery the infants were examined by a paediatrician for clinical signs of $\mathrm{CDH}$. In 39 children $(0 \cdot 8 \%) \mathrm{CDH}$ was diagnosed and confirmed by radiological examination. Of these the umbilical cords from the $10(0 \cdot 2 \%)$ with completely

Received 1 March 1976. dislocatable hips, 7 girls and 3 boys, were selected and examined.

From the umbilical cord 5 or 6 slices 3-4 mm thick were taken for examination. Blood was rinsed off in distilled water at a temperature of $0^{\circ} \mathrm{C}$. The slices were frozen in liquid nitrogen and crushed in a steel mortar. The crushed tissue was placed in a glass container with 4 times its wet weight of $0.5 \mathrm{~mol} / 1$ acetic acid. Extraction was continued for 24 hours at $4^{\circ} \mathrm{C}$ with constant shaking. Separation was carried out in a centrifuge at $20000 \mathrm{~g}$ for 1 hour and at a temperature of $4^{\circ} \mathrm{C}$. The supernatant was decanted. An aliquot of each supernatant was dialysed against distilled water for 24 hours in order to separate the smaller polypeptides that are split off when the tissue is crushed in liquid nitrogen. The dialysis sack will allow peptides with a molecular weight $<12000$ to escape. Using a modification of the method described by Stegeman (Pikkarainen, 1968; Woessner, 1961) the amount of hydroxyproline was determined in the two fractions of the supernatant and in the sediment. The amount of collagen was calculated as hydroxyproline $\times 7 \cdot 1$.

In order to study a more homogeneous tissue we also examined the veins from the umbilical cords after careful dissection, as described above. Umbilical cords from 10 normal infants served as controls.

\section{Results}

Large variations were found in both groups. The variation in collagen content was less in the veins than in the cord cross-sections (Table). The collagen content was less in CDH children when compared with controls, significantly so only in the vein samples. Extractable collagen was decreased in $\mathrm{CDH}$ children. The values of the nondialysed fraction differed significantly only in the cord 
TABLE

Amount and solubility of collagen in umbilical cords of $10 \mathrm{CDH}$ children and 10 controls (mean $\pm S D$ )

\begin{tabular}{|c|c|c|c|}
\hline & \multirow{2}{*}{$\begin{array}{c}\text { Total collagen } \\
\text { (mg/g wet weight) }\end{array}$} & \multicolumn{2}{|c|}{ Extractable collagen (mg/g wet weight) } \\
\hline & & Nondialysed & Dialysed \\
\hline $\begin{array}{l}\text { Cross-section of umbilical cord } \\
\text { CDH } \\
\text { Control } \\
\text { Vein of umbilical cord } \\
\text { CDH } \\
\text { Control }\end{array}$ & $\begin{array}{l}30 \cdot 84 \pm 7 \cdot 48 \\
38 \cdot 88 \pm 11 \cdot 34 \\
0 \cdot 1>P>0 \cdot 05 \\
25 \cdot 30 \pm 3 \cdot 50 \\
28 \cdot 75 \pm 3 \cdot 46 \\
0 \cdot 05>P>0 \cdot 01\end{array}$ & $\begin{array}{l}0 \cdot 198 \pm 0.057 \\
0 \cdot 275 \pm 0.041 \\
0.005>P>0.001 \\
0 \cdot 241 \pm 0.075 \\
0 \cdot 252 \pm 0.060 \\
P>0.1\end{array}$ & $\begin{array}{l}0 \cdot 158 \pm 0.081 \\
0 \cdot 197 \pm 0.022 \\
P>0 \cdot 1 \\
0 \cdot 124 \pm 0.056 \\
0 \cdot 183 \pm 0.048 \\
0 \cdot 05>P>0.01\end{array}$ \\
\hline
\end{tabular}

cross-sections. The dialysed collagen differed between the two sets of children both in the vein samples and in the cord sections. In the latter there was a significant difference in standard deviations $(\mathbf{P}<0 \cdot 001)$.

\section{Discussion}

The tensile properties of connective tissue depend on collagen. The collagen content of connective tissue is decreased after administration of oestrogens (Fischer, 1972; Henneman, 1968). Instability of the hip in animals can be provoked by oestrogen (Gustafsson, 1968, 1975; Gustafsson and Beling, 1969; Månsson and Norberg, 1961; Zaffaroni 1958). During pregnancy the fetus is exposed to high concentrations of oestrogens. An increased frequency of inguinal hernia in girls with $\mathrm{CDH}$ was reported by Fredensborg (1976), and Wagh et al. (1974) found a decreased amount of collagen in the anterior rectus sheath in patients with direct inguinal hernia.

The results of the present investigation have shown that the collagen content of connective tissue of children with $\mathrm{CDH}$ is decreased. This may explain the increased laxity of their joints and the instability of their hips. A possible explanation might be that the water content differed in samples from $\mathrm{CDH}$ children and controls, but when we measured the water content in another sample of veins of umbilical cords from $\mathrm{CDH}$ and control children, there was no difference. The difference in solubility indicates a difference in quality. There are, so far, 4 types of collagen. Type $I$ is predominant in skin, tendons, and bones. Type III is the typical constituent of arterial walls and is the dominant fetal type of collagen. Fetal collagen is less soluble than adult collagen (Miller, 1973). The findings of the present study could be explained either by a different proportion of type I and type III collagen, a decreased synthesis of collagen, or a difference in cross-linking in children with $\mathrm{CDH}$. Our findings support the theory that $\mathrm{CDH}$ is a consequence of changes in the connective tissue supposed to maintain the stability of the joint rather than of changes in the bony structures.

Financial support was received from the Swedish Medical Research Council (project no. B75.17X-273707C) and the Herman Järnhardt Foundation.

\section{REFERENCES}

Andrén, L. (1960). Instability of the pubic symphysis and congenital dislocation of the hip in newborns. Acta Radiologica, 54, 123.

Andrén, L., and Borglin, N. E. (1960). A disorder of oestrogen metabolism as a causal factor of congenital dislocation of the hip. Acta Orthopaedica Scandinavica, 30, 169.

Andrén, L., and Borglin, N. E. (1961a). Disturbed urinary excretion pattern of oestrogens in new-borns with congenital dislocation of the hip. I. The excretion of oestrogens during the first few days of life. Acta Endocrinologica, 37, 423.

Andrén, L., and Borglin, N. E. (1961b). Disturbed urinary excretion pattern of oestrogens in new-borns with congenital dislocation of the hip. II. The excretion of exogenous oestradiol17ß. Acta Endocrinologica, 37, 427.

Carter, C., and Wilkinson, J. (1964). Persistent joint laxity and congenital dislocation of the hip. Fournal of Bone and foint Surgery, 46B, 40.

Fischer, G. M. (1972). In vivo effects of estradiol on collagen and elastin dynamics in rat aorta. Endocrinology, 91, 1227.

Fredensborg, N. (1976). Observations in children with congenital dislocation of the hip. Acta Orthopaedica Scandinavica, 47, 175.

Grant, M. E., and Prockop, D. J. (1972). The biosynthesis of collagen. New England fournal of Medicine, 286, 194.

Gustafsson, P. O. (1968). Hip dysplasia in the greyhound: a study of estradiol induced skeletal changes. Fournal of the American Veterinary Radiological Society, 8, 47.

Gustafsson, P. O. (1975). Estradiol-induced skeletal changes: the long term effect of prenatal and postnatal administration in beagles. Acta Radiologica, Suppl. 344, 53.

Gustafsson, P. O., and Beling, C. G. (1969). Estradiol-induced changes in beagle pups: effect of prenatal and postnatal administration. Endocrinology, 85, 481 .

Henneman, D. H. (1968). Effect of estrogen on in vivo and in vitro collagen biosynthesis and maturation in old and young female guinea pigs. Endocrinology, 83, 678.

Jackson, D. S., and Bentley, J. P. (1960). On the significance of the extractable collagens. Fournal of Biophysical and Biochemical Cytology, 7, 37.

Mánsson, J., and Norberg, I. (1961). Höftledsdysplasi hos hund. Medlemsblad för Sveriges Veterinärförbund, 13, 330. 
Miller, E. J. (1973). A review of biochemical studies on the genetically distinct collagens of the skeletal system. Clinical Orthopaedics, 92, 260.

Pikkarainen, J. (1968). The molecular structures of vertebrate skin collagen. A comparative study. Acta Physiologica Scandinavica, Suppl. 309, 22.

Wagh, P. V., Leverich, A. P., Sun, C. N., White, H. J., and Read, R. C. (1974). Direct inguinal herniation in men: a disease of collagen. fournal of Surgical Research, 17, 425.

Woessner, J. F. (1961). The determination of hydroxyproline in tissue and protein samples containing small proportions of this amino acid. Archives of Biochemistry and Biophysics, 93, 440.
Wynne-Davies, R. (1970). Acetabular dysplasia and familial joint laxity: two etiological factors in congenital dislocation of the hip. Fournal of Bone and foint Surgery, 52B, 704.

Zaffaroni, A. (1958). Hormones and meat production from livestock. Recent Progress in Hormone Research, 14, 212.

Correspondence to Dr. N. Fredensborg, Department of Orthopaedic Surgery, Malmö General Hospital, S-214 01 Malmö, Sweden. 